\title{
Gulliver Effect in Macroeconomic Policies of Landlocked Developing Countries: A Comparative Study
}

\author{
Ramesh C. Paudel, Ph. D. ${ }^{1}$ \\ ReshamThapa-Parajuli ${ }^{2}$
}

\begin{abstract}
This paper analyses the different macroeconomic indicators of three landlocked developing countries to identify the Gulliver effect. Initially, it analyses the trade and economic size of Botswana, Lao PDR, and Nepal corresponding to their respective big neighbour South Africa, Thailand, and India, respectively. The paper further analyses the major macroeconomic indicators of these landlocked developing countries.The findings signal for the existence of the Gulliver effect in trade. Moreover, the paper extendsthe analysis of the Gulliver effect in inflation, interest rate and exchange rates. The findings support the presence of the Gulliver effect. The study found that prime macroeconomic variables of these landlocked developing countries move in a similar direction following almost similar pattern with those of Gulliver neighbours in different magnitudes though.
\end{abstract}

Key words: Trade, International trade, Macroeconomic policies, Landlocked countries, JEL classification: F10, P33, E60, O53

\section{Introduction}

The role of macroeconomic policies in economic development is a stylised fact, which has received numerousattentionsfrom the economists and policymakers in the global context.A neighbour is the sources of knowledge for human beings, the policymakers of the landlocked developing countries (LLDCs), typically have a substantial influence from their neighbours' macroeconomic policies. Thus, it is crucial to know whether their big neighbours' macroeconomic policies highly influence the LLDCs' macroeconomic policies. Here, the big neighbour refers to the neighbouring country with a relatively larger economy, influential cultural and other relationshipbetween the countries' people to people due to religion and language tie-up; or tradeand other economic relationships between corporate to corporate

1 Dr. Paudel is visiting fellow at the Australian National University, Canberra, Australia. email: ramesh.paudel@alumni.anu.edu.au

2 Mr. Thapa-Parajuli is an Assistant Professor at the Central Department of Economics, TU. email: resham3@gmail.com 
level or institution to institution level, and government-to-government of the countries.

In addition to this, because of the constraints imposed by landlockedness, LLDCs' policymakers feel dominated to such big neighbours' bureaucratic mechanism and most of the relevant areas. It is believed that there is always a kind of influence from the big neighbour to small one due to scale of economies, transportation and trade costs, and economic efficiency (Charaf $\square$ Eddine \& Strauss, 2014). Similarly, this nature of relationships may exist in terms of economic policies toopaving the way for theGulliver effect (GE) from their bigand comparatively advancedneighbours'macroeconomic policies to poor, dominated, underdeveloped, and disadvantaged countries. The concept of Gulliver effect is not only intellectually important but also significant implication in policy analysis. Gulliver effect is a familiar concept in social sciences, especially to compare a small object with the big one how a big object has a direct or indirect impact in small objects. This concept suits to study the small landlocked countries' macroeconomic policies, which are influenced by their big neighbours' macroeconomic policies.

Blejer (1991) studied the Gulliver effect in Nepal analysing the impact of India's trade policies in Nepal's trade policies. Also, time to time, there seems a youth's voice that indicates a suspicion ofNepal's politicians and policymakers are highly influenced by Indian politicians, policymakers, and bureaucratic mechanisms. In this background, this study extendsBlejer (1991) in two stands: first, instead of just trade policies, this study aims to analyse macroeconomic policies; second, it makes a comparative study of this effect in three LLDCs with their Gulliver neighbours.

The paper aims to seek the answersto some of the specific questions,such as, whether there is a Gulliver effect in the macroeconomic policies of a landlocked developing country. Furthermore, is the Gulliver effect a common phenomenon in LLDCsregarding three LLDCs: Botswana, Lao PDR and Nepal?

The Gulliver effect in macroeconomic policy has not been studied systematically yet in Economics. This research aims to bridge this gap.For this, the paper wants to make a comparative study analysis. For this, we select three landlocked developing countries: Botswana, Lao PDR and Nepal, which have big economies in their neighbourhoodand represent three different regions. For the comparative study, these three countries have some similarities and differences.Firstly on similarities, they all are landlocked developing countries with big neighbour such as Botswana has South Africa as a big neighbour, Lao PDR has Thailand and China in the neighbourhood, and Nepal has two big such economies of India and China. Secondly, on differences, the size of these countries' economies, population, land area, history, culture, and geographical factors are substantially diverse. Even among these three countries, Botswana's economic performance is impressive compared to that of Lao PDR and Nepal. A systematic comparison of macroeconomic policies of these countries considering the Gulliver effect from their big neighbours would help to answer the research questions of this study.

The outline of this paper is as follows: Section 1 covers introduction. The policy context is discussed in Section 2. Gulliver neighbour is dealt with in Section 3. The growth outcomes 
and trade performance of the selected landlocked countries are explained inSection 4. Section 5 analyses the Gulliver effect on macroeconomic policies of the landlocked developing countries, namely Botswana, Lao PDR and Nepal, before concluding in the final section. And the conclusion is in the final section.

\section{Selected Landlocked Countries and Their Policy Contexts}

More than just being landlocked and having a big neighbour, Botswana, Lao PDR and Nepal have different records in their favour. Botswana's economic growth is historical, and it was one of the fastest-growing economies in the World. Lao PDR, the natural resourcerich country has passed different political regimes and many shifts in her macroeconomic policies. Nepal has never been colonised in her long history of foundation. It has some unique features of political transformation. Notably, Nepal has passed four different political regimes in the last half-century. Probably, Nepal is one of the unfortunate countries in terms of economic growth despite being one of the wealthiest countries in natural resources and hydropower(Upadhaya, 2008). If the growth and trade performances of these countries are compared, we find a big difference. So, what makes such differences in economic and trade performance? This scenario creates doubt of the Gulliver effect in macroeconomic policies too as in the international trade.

Botswana is a small country compared to its neighbour in Africa region andnow categorised as an upper-middle-income country by the World Bank. Botswana became independent in 1966 from a British colony with a total land of 5, 70,000 square kilometres and had a total population of just above two million in 2010. Botswana's growth performance is highly impressive not only in Africawhere the growth rate has depressed due to many reasons but also in the World(Beaulier, 2003; Hillbom, 2011). Most of the literature agrees that Botswana achievedthese results due to its sound policies and quality of governance. In this regard, Acemoglu et al., (2001) concludes with five major points that lead Botswana's impressive economic growth. First, Botswana is very rich in natural resourcewealth; second, it had unusual pre-colonial political institutions that lead a good participation in the political process and placed many restrictions on the political power of the elites; third, British colonial rule was limited allowing pre-colonial institutions to survive to the independence era; fourth, it exploited comparative advantage of the nation immediately after the independence adopting suitable policy changes; and fifth, the political leadership inherited the legitimacy of these institutions and allowed a broad political base in the country.

Lao PDR with a total of 2, 30,800 square kilometres land and a total population of just above six million (in 2010) has performed relatively well in the last decade despite some setbacks of Global Financial Crisis (GFC). Even being a landlocked country, Lao PDR is one of the best performers in the region at this stage. It has a long battle with foreign powers initially with France and later with the USA. Since 1975, Lao PDR got freedom from foreign powers and established a peaceful country since then, and mostly has maintained a peaceful with improving the quality of governance. From 1986, Lao PDR started market-oriented economy maintaining political stability and achieved more than moderate economic growth- 
boosting investment (Kyophilavong, Uddin, \& Shahbaz, 2016).However, it is blamed to be more aid-dependent for the development (St John, 2006).

Nepal is another landlocked country, which is smaller than Botswana and Lao PDR in terms of the land area of 1,47,181 square kilometres and more prominent in terms of population: almost 28 million (in 2010). In political history, it was ruled by Rana regime (elite feudal) for 104 years, until 1951; however, this small country was never colonised. Nepal started building some institutions with first five-year development plan from 1956; but dominantly, it was a mixed economy approach. In 1961, monarchy controlled the power and became active to suppress the political parties and run the country with a party-less political system called 'Panchayat System' until 1991 (Shrestha, 2005). Nepal is also known as one of the significant aid recipients countries, but the effectivity seems questionable (Sharma \& Bhattarai, 2013).

Political reform was made due to political movement and "Multiparty System" was re-established. Again, before settling the democracy in full shape, since 1996, the country had to be suffered from arm struggle run by Nepal Communist Party-Maoist (CPN-Maoist) that aim to capture the state with bullet's force. Due to the ineffective role of leadership of major political parties of that time, i.e. Nepali Congress (NC) and Communist Party of Nepal -Unified Marxist and Leninist (CPN-UML) and over-ambition of the then king GyanendraBir Bikram Shah, Monarchy system was reintroduced in 2005 with many attempts in different phases. Against the direct rule of the king, all political parties including CPN-UML, NC and CPN-Maoist made solidarity to remove the 240 years old monarchy system through peaceful movement in 2006 and formally, the monarchy was abolished in 2007/08 from re-established parliament. Since then, the country is running in transition, and still, political turmoil is there in different forms and has not progressed well in economic policies, reform and economic development. Nepal particularly needs to work out in second generational reform with the priority of policy consistent.

\section{Selecting a Big Neighbour-The Gulliver Neighbour}

These three landlocked developing countries' macroeconomic indicators provide some interesting information needed for the analysis. Botswana has Namibia, South Africa, Zambia and Zimbabwe in her neighbour. Among these, South Africa is the largest trading partner in the neighbour. In addition to this, South Africa is the largest trading partner of Botswana in the World, since 2007, when South Africa took over the position in a trading partner from the United Kingdom (UK).

Lao PDR has five countries, such as Burma, Cambodia, China, Thailand, and Vietnam, in her neighbour. It has the largest trading partnership with Thailand. Lao PDR's trade with Thailand also is mostly dominated by imports. The cultural, language and people to people level tie-up is there between these two countries.

Unlike Botswana and Lao PDR, Nepal has only two neighbours, i.e. China and India. Nevertheless, in terms of trade until now,India is the largest trade partner of Nepal. The 
majority portion of the international trade of Nepal is via India from where Nepal imports far higher than that of exports. This way, themost prominent neighbour of a landlocked country is selected based on her trade relationship in the neighbouring countries.

The selection of data up to 2010 related to trade openness, government consumption and investment uses the Penn World Table version 7.1 (Heston et al., 2012) data base, which have the maximum data period up to 2010 .

Table1 shows that South Africa is a significant player in the international trade of Botswana and the figures suggest that more than 40 percent of the total trade of Botswana is with South Africa. Similarly, more than 50 percent of the total international trade of Lao PDR occurs in Thailand. These data for Nepal record more than 60 percent in the later stage with India.This trend of international trade in these countries seems to be an old fashioned. Therefore, this situation motivates to analyse the Gulliver effect of South Africa's macroeconomic policies on Botswana's macroeconomic policies, Thailand's macroeconomic policies on Lao PDR's macroeconomic policies, and India's macroeconomic policies on Nepal's macroeconomic policies.

Table1: Total Trade (in million US\$)

\begin{tabular}{|l|c|c|c|c|c|c|}
\hline \multirow{2}{*}{ Years } & \multicolumn{2}{|c|}{ Botswana } & \multicolumn{2}{c|}{ Lao PDR } & \multicolumn{2}{c|}{ Nepal } \\
\cline { 2 - 7 } & South Africa & World & Thailand & World & India & World \\
\hline 2000 & 1704.17 & 4823.00 & 487.9 & 1081.1 & 881.40 & 2291.00 \\
\hline 2005 & 3047.98 & 7589.38 & 1050.6 & 1996.9 & 1770.7 & 2882.6 \\
\hline 2006 & 2908.62 & 7552.93 & 1600.9 & 2879.1 & 2044.5 & 3227.3 \\
\hline 2007 & 3847.08 & 9049.07 & 1873.6 & 3430.8 & 2509.3 & 3964.7 \\
\hline 2008 & 4934.71 & 10100.00 & 2493.5 & 4437.5 & 2723.7 & 4450.2 \\
\hline 2009 & 4103.02 & 8173.45 & 2224.2 & 4413.5 & 1947.30 & 3385.20 \\
\hline 2010 & 4724.43 & 10300.00 & 3038.1 & 5771.2 & 2558.00 & 4457.70 \\
\hline
\end{tabular}

Source: Botswana from UNCOMTRADE and Lao PDR \& Nepal from Asian DevelopmentBank as of 2012.

\section{Growth Outcomes and Trade Performance}

Botswana is one of the fastest-growing economies in the World, which had \$1308 per capita GDP, followed by $\$ 537$ of Lao PDR and \$580 of Nepal in 1970 (Table-2). Botswana grew on average of almost of five and a half percent over the period from 1970 to 2010, and her per capita GDP reached to US\$9450, while Lao PDR grew on average of just above four percent for the same period and per capita GDP reached to US\$2534 in 2010. Nepal grew on average, just above one and a half percent for the same period, and per capita GDP is recorded US $\$ 1150$ for the same period. A notable point here is that Botswana's per capita GDP has inclined to more than seven folds; while, Lao PDR's per capita GDP has increased 
to close to five-folds, and Nepal's per capita GDP has increased to less than two folds only over this period despite facing the constraints of Landlockedness by all of these countries. Their trade policy might be crucial as discussed in Paudel (2014a).

Further, the figures in the table show that Botswana had more than five percent on average per capita income growth until 1990, which was slowed after 1990. On the other hand, Lao PDR and Nepal have the opposite scenario, i.e. both countries started growing comparatively faster after 1990. Nepal's average 10-year growth rate never reached five percent. Botswana has a record of 10 percent average of 10-year growth in 1980, Lao PDR has a record of six and a half percent average 10-year growth in 2010; Nepal has a record of almost three and a half percent average of 10-year growth rate in last decade.For the growth situation, these three countries have different political and historical perspectives that played a significant role to influence their economic policies to have such growth performances. Botswana's economic growth led her to be upper-middle-income country and hopefully, she will be graduated soon to a high-income country. Lao PDR and Nepal lie still in the low-income category.

In terms of exports growth, Botswana has a substantial exports growth until 2000 and a moderate decline in the last decade due to GFC in 2008 and 2009. The major export items for Botswana include diamond (more than 60 percent), copper, nickel, beef and textile. The exports growth of Lao PDR seems to be very impressive despite negative growth in 2000 due to AFC and in 2007 due to GFC.Nepal's exports areseverely affected by politicalshakiness, strikes and power shortage in the last decade.However, this is the period of highest average 10 -year per capita growth.

Table 2: Export and Growth Trends

\begin{tabular}{|c|c|c|c|c|c|c|c|c|c|}
\hline \multirow[b]{2}{*}{ Years } & \multicolumn{3}{|c|}{ Botswana } & \multicolumn{3}{|c|}{ Lao PDR } & \multicolumn{3}{|c|}{ Nepal } \\
\hline & $\begin{array}{c}\text { RGDPPC } \\
\text { (PPP, } \\
\text { US\$) }\end{array}$ & $\begin{array}{c}\text { RGDPPC } \\
\text { growth } \\
\%(10 \\
\text { year } \\
\text { average) }\end{array}$ & \begin{tabular}{|c} 
Export \\
Growth \\
$\%(10$ \\
year \\
average)
\end{tabular} & $\begin{array}{c}\text { RGDPPC } \\
\text { (PPP, } \\
\text { US\$) }\end{array}$ & $\begin{array}{c}\text { RGDPPC } \\
\text { growth } \\
\%(10 \\
\text { year } \\
\text { average) }\end{array}$ & \begin{tabular}{|c} 
Export \\
Growth \\
$\%(10$ \\
year \\
average)
\end{tabular} & $\begin{array}{c}\text { RGDPPC } \\
\text { (PPP, } \\
\text { US\$) }\end{array}$ & $\begin{array}{c}\text { RGDPPC } \\
\text { growth } \\
\%(10 \\
\text { year } \\
\text { average) }\end{array}$ & $\begin{array}{c}\text { Export } \\
\text { Growth } \\
\%(10 \\
\text { year } \\
\text { average) }\end{array}$ \\
\hline 1970 & 1308 & 5.9 & & 537 & - & & 580 & 0.9 & - \\
\hline 1980 & 3241 & 10 & - & 666 & 2.2 & - & 589 & 0.2 & - \\
\hline 1990 & 6349 & 6.9 & 11.39 & 935 & 3.6 & - & 721 & 2.1 & 17.2 \\
\hline 2000 & 8361 & 2.9 & 3.59 & 1356 & 3.8 & 5.1 & 834 & 1.5 & 2.44 \\
\hline 2010 & 9450 & 2 & -1.82 & 2534 & 6.5 & 20.75 & 1150 & 3.3 & \\
\hline $\begin{array}{l}1980 \\
-2010\end{array}$ & & 5.4 & & & 4.1 & & & 1.6 & \\
\hline
\end{tabular}

Source: World Bank (2012)

The trade deficit has become a significantchallenge of the international trade of Lao PDR and Nepal for almost two decades.Botswana also has this problem in the last decade. However, unlike Lao PDR and Nepal, Botswanahasadopted an effective exports promotion 
strategy since 1979 and has gained.

The sectoral contribution of GDP in Botswana seems to be substantially different from Lao PDR and Nepal, such as the contribution from the agriculture sector in Botswana was very low. The share of the service sector has increased significantly in all three countries, and the manufacturing sector has not significantly progressed in any of these countries. The highest contribution of agriculture sector in 2010 was found in Nepal that is almost 40 percent, and almost 30 percent for Lao PDR and two percent for Botswana. The problem of Nepalese agriculture sector is that it largely depends on monsoon(Thapa-Parajuli \& Devkota, 2016). The industry sector is the second largest contributor in Botswana with almost 45 percent, Lao PDR about 30 percent and Nepal has the lowest at almost 15 percent (Table 3). The difference between industry and manufacturing is that industry includes construction and mining. The manufacturing sector's contribution is better in Lao PDR in the later stage.

Table 3: Sectoral Contribution in GDP

\begin{tabular}{|l|l|c|c|c|c|c|}
\hline Countries & Sectors & $\mathbf{1 9 8 0}$ & $\mathbf{1 9 9 0}$ & $\mathbf{2 0 0 0}$ & $\mathbf{2 0 0 5}$ & $\mathbf{2 0 1 0}$ \\
\hline \multirow{4}{*}{ Botswana } & Agriculture & 15 & 5 & 3 & 2 & 2 \\
\cline { 2 - 7 } & Industry & 51 & 61 & 53 & 50 & 45 \\
\cline { 2 - 7 } & Manufacturing & 5 & 5 & 5 & 4 & 4 \\
\cline { 2 - 7 } & Service & 35 & 34 & 45 & 48 & 52 \\
\hline \multirow{4}{*}{ Lao PDR } & Agriculture & - & 61 & 45 & 36 & 33 \\
\cline { 2 - 7 } & Industry & - & 15 & 17 & 25 & 32 \\
\cline { 2 - 7 } & Manufacturing & - & 10 & 6 & 10 & 7 \\
\cline { 2 - 7 } & Service & - & 24 & 38 & 39 & 35 \\
\hline \multirow{4}{*}{ Nepal } & Agriculture & 62 & 52 & 41 & 36 & 37 \\
\cline { 2 - 7 } & Industry & 12 & 16 & 22 & 18 & 16 \\
\cline { 2 - 7 } & Manufacturing & 4 & 6 & 9 & 8 & 7 \\
\cline { 2 - 7 } & Service & 26 & 32 & 37 & 46 & 48 \\
\hline
\end{tabular}

Source: World Bank (2012)

Some of the macroeconomic indicatorsare more relevant to compare these landlocked countries' economic performance like openness, budget deficit, investment and monetary expansion that help to understand the macroeconomic policies of a country. These have been compared among Botswana, Lao PDR and Nepal based on their data.

\section{Structural Change and Openness}

Botswana is one of the quick catchers of reform and liberalisation phases among not only the developing countries but also comparing many developed countries. Lao PDR's reform process was started very late compared to Botswana due to political turmoil from foreign players, i.e. France and the USA. Lao PDR started a smooth political transition phase in the late 1980s, then started a slow phase reform in her economy. Nepal started financial reform in since1984 
with interest rate deregulation and with many phases, a fast speed of reform was gained from 1991 easing credit control, reforming external account and strengthening the private sector for investment. However, doing this always may not contribute to faster economic growth and trade performance (R. C. Paudel \& Kankesu, 2009).

One of the significant indicators of policy direction in development economics is the openness-trade reform, which is measured in three ways likeSachs and Warner criteria for openness, tariff rates and trade to GDP ratio in the literature. All these methods have their shortcomings, but jointly they provide more reliable information to enhance the discussion and analysis. In terms of updated Sachs and Warner, Botswana becomes open from 1979, Nepal from 1991 and Lao PDR remains closed despite lowering the tariff rate, and there is no enough evidence to suggest it as an openeconomy. Botswana has virtually made its weighted average tariff rate less than eight percent on average, for Lao PDR, it is recordedjust above 10 percent, which has been up and down maintaining below 15 percent in the last decade. Among these three countries, Nepal has the highest tariff rate, which is almost 14 percent on average and fluctuation is there from 13 percent to 16 percent(R. Paudel, 2014).

Another way of assessing the openness in the empirical literature is to measure the share of total trade in GDP in percentage. For this, the share of total trade in GDP in percentage has been used, and the data used to construct this share are in 2005 constant price. The openness indicator in this category shows Botswana has the highest index throughout the period from 1960 to 2010.There was a sharp incline of this openness in Botswana from 1967 to 1977, reached to 118 percent, then fluctuated to have a peak, i.e. 125 percent in 1987, then declined gradually to 70 percent in 2009 (Figure-1). Lao PDR had only 13 percent share of total trade in her GDP in 1970 , and then started to increase with many fluctuationsfrom 1987 to 2008 , reached to 80 percent and then declined to about 60 percent. Nepal had only 12 percent share of total trade in GDP in 1960, which gradually with fluctuationreached up to 64 percent in 1997, then declined with many fluctuations. This indicator shows that Botswana and Lao PDR are in a better position than Nepal that hasa relatively weak share of total trade in her GDP in the last one and a half decades.

Figure 1: Trade OpennessScenario

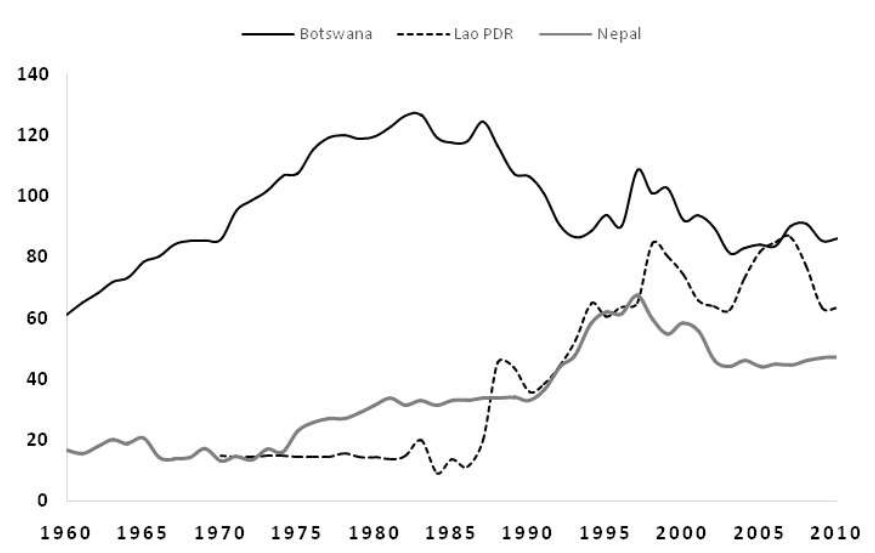

Source: Author's calculation using data from Penn World Table version 7.1 (Heston et al., 2012). 
26 | The Economic Journal of Nepal (Issue No. 149)

\section{Government Consumption}

Government consumption indicates the nature ofpublic finance in the country, and it explains the absorption capacity of an economy. The government consumption with high administrative expenditure becomes a burden for a country. The development expenditure isgenerally categorised as an investment. Hence, in this case, higher government expenditure refers to the higher administrative burden.

Figure2 presents the picture of government consumption in these three countries using data of the share of government consumption to GDP measured by PPP constant 2005 price level. This figure suggests that Lao PDR has the highest government expenditure throughout the period from 1970 to 2010 and remained above 15 percent to a significant number of periods. It had a sharp incline to 23 percent in 2010 from 14 percent in 2003. Botswana has more fluctuation over the period, but it has remained in between five percent to 12 percent. The data for Nepal suggest that it has remained in six percent to 12 percent, a gradual increase is found since 2001 with some fluctuations.

Figure 2: Government Consumption

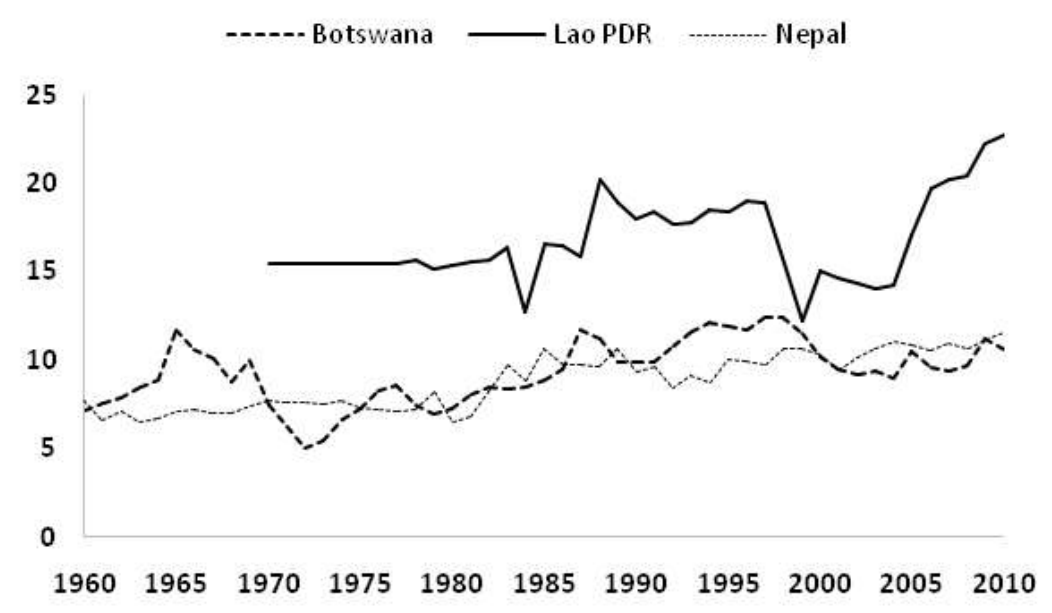

Source: Author's calculation using data from Penn World Table version 7.1 (Heston et al. 2012).

\section{Investment}

Investment is the backbone of economic development of a country. It has mostly been measured by theinvestment share of Purchasing Power Parity converted GDP Per Capita at constant prices. The data for investment share in GDP measured by PPP constant 2005 price level is used for these three countries (Figure-3). Botswana has the highest share of 
investment compared to the other two countries from1960 to 2010. During this period, Botswana has made a heavy investment in physical and human capital to achieve a high extended growth rate. Botswana has a sharp increase of the investment share in 1970 to 60 percent, then remained above 60 percent until 1974, then declined with some fluctuation to 20 percent in 1987, and then with substantial fluctuation remained about 50 percent.

The investment share of Lao PDR remained the lowest until 2001 then overshoot to the share of Nepal, maintaining above 20 percent. Nepal has a trend of gradual increase in investment with moderate fluctuation throughout the period, and the share is recorded about 25 percent in the last decade.

Figure 3: Investment

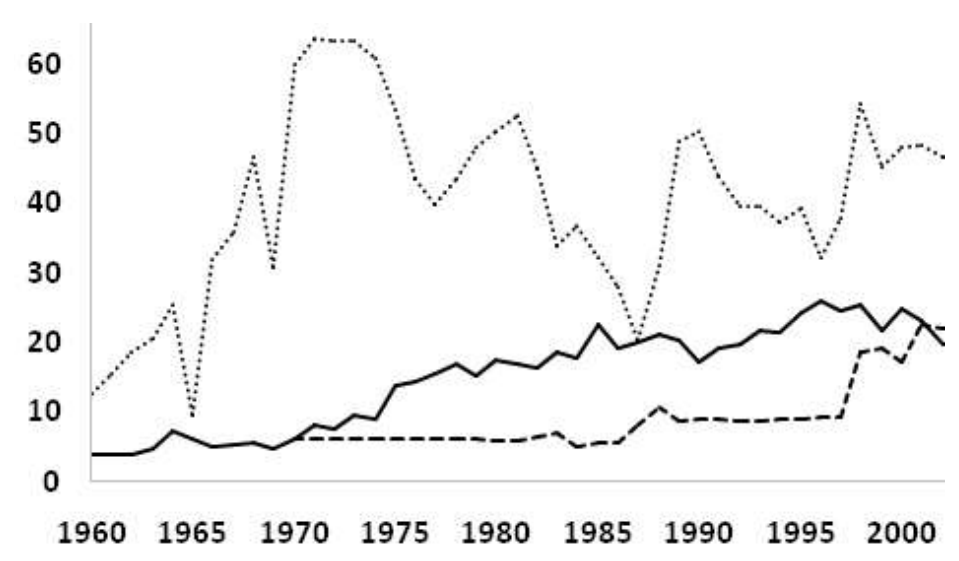

Source: Authors' calculation using data from Penn World Table version 7.1 (Heston et al. 2012).

\section{Gulliver Effect in Macroeconomic Policies}

Being landlocked countries; Botswana, Lao PDR and Nepal may not have a reliable option rather than to follow their Gulliver neighbour's macroeconomic policies. Several reasons play for this situation: border management, cultural and language tie-up among the people in the border areas of countries, plus their trade relationship with such country in the neighbour. Thus, these three small landlocked countries'macroeconomic indicators such as price level, exchange rate and interest rate, which seem to have strong association; are compared with those of big neighbours to identify the Gulliver effect if any.

\section{Price Level}

Price level reflects the situation of the public welfare in a country. This variable is widely affected by the neighbour's price level in this era of globalisation. Considering this fact, the price levels of these three countries have been compared with the price levels of their most prominent neighbours using constant 2005 price level data. Figure4 presents the picture of the price level 
28 | The Economic Journal of Nepal (Issue No. 149)

of Botswana and her most prominent neighbour South Africa. The trends of both price levels are almost similar, as can be seen in the figure, both price levels are almost co-integrated until 1985. The price level of South Africa is slightly higher than of Botswana until 2005 with the almost same trend, and then the price level of Botswana has led to South Africa. Both series have inclined gradually maintaining a similar trend during the period. It clearly shows that Botswana has been able to maintain the inflation rate close to that of South Africa- the largest trading partner.

Figure 4: Consumer Price Index Botswana and South Africa

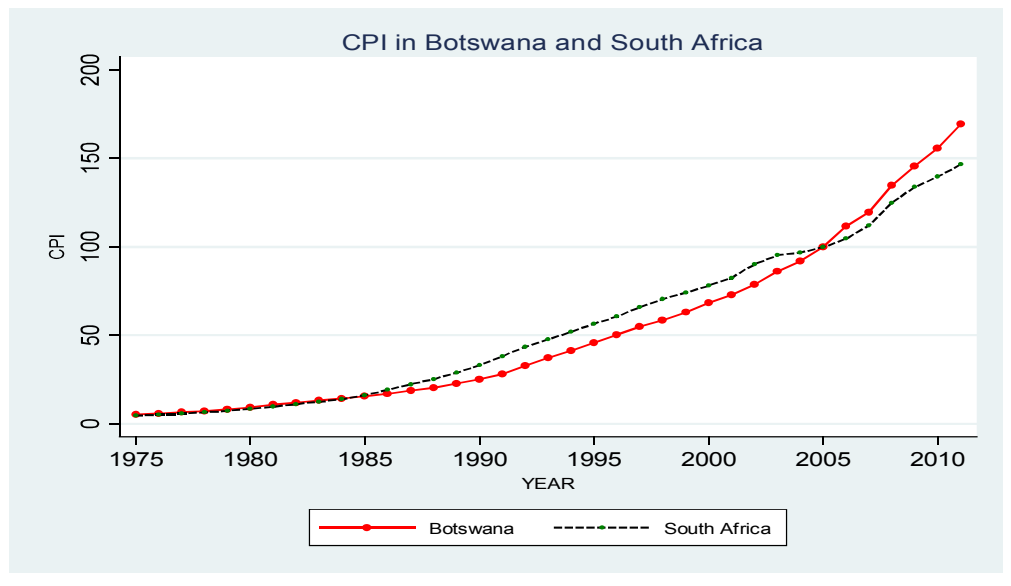

Source: Authors' calculation from the World Bank (2012) database.

Figure 5 shows the relationship between the price levels of Lao PDR and Thailand. The relationship, in this case, does not look as strong as in the case of Botswana and South Africa, and Nepal and India.

Figure 5: Consumer Price Index:Lao PDR and Thailand

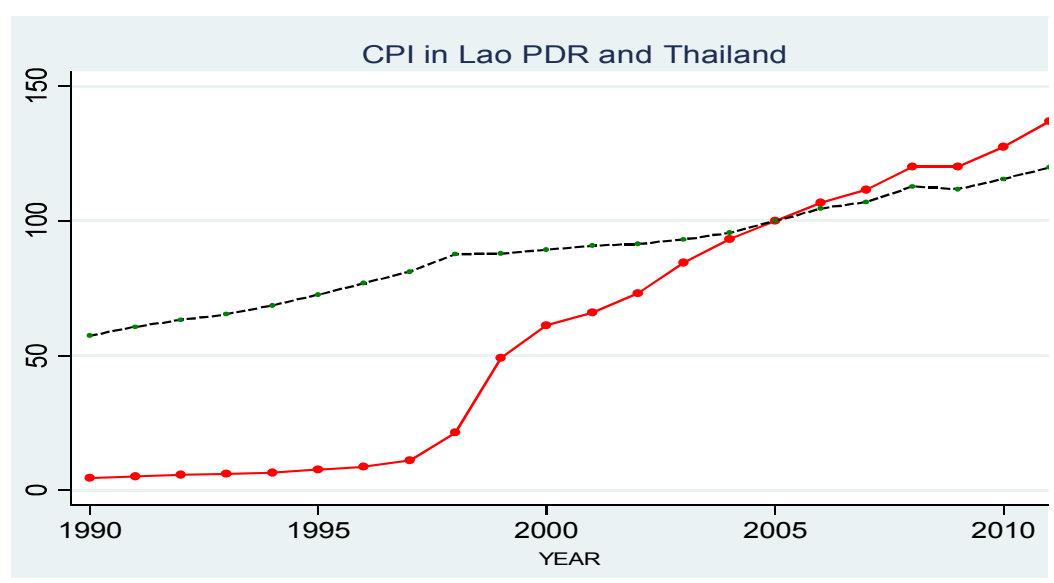

Source: Authors' calculation from the World Bank (2012) database 
Figure6 presents the price levels of Nepal and India from 1965 to 2010. The price levels for both countries are integrated for the entire period.The relationship seems to be stronger than the case of Botswana and Lao PDR. Since 2005, both the price levels have increased sharply. Because of the open border between Nepal and India, the price level cannot be much different, and the market adjusts considering the border areas of these two countries. Nepalese customer can easily purchase the goods from local areas of India if the price level in Nepal is higher and vice versa. This situation has been reflected in the relationship between the price levels of both countries.

Figure 6: Consumer Price Index Nepal and India

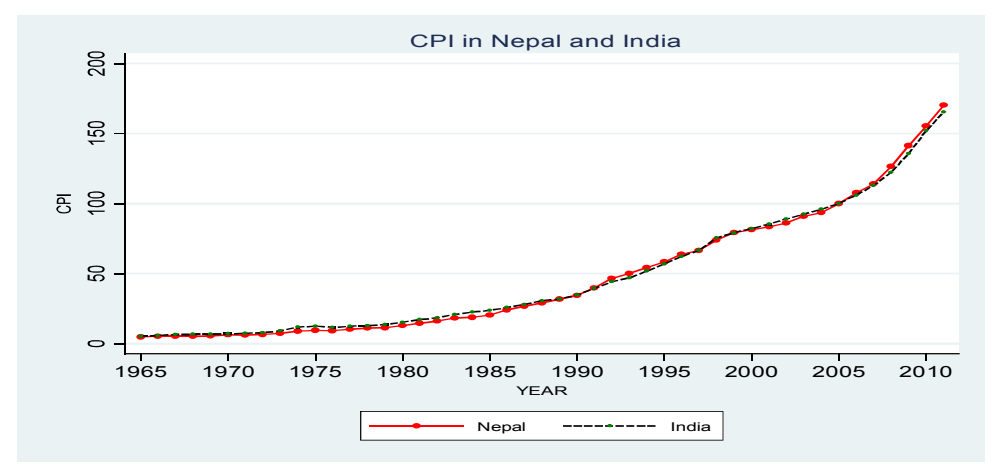

Source: Authors' calculation from the World Bank (2012) database

\section{Interest Rate}

The real interest rate (inflation-adjusted interest rate) for the pair of countries is compared to ease the analysis. Figure-7 shows that the real interest rate in Botswana has many fluctuations compared to the real interest rate of South Africa from 1980 to 2010. Botswana's real interest rate has been managed within the boundary of negative 15 percent to 20 percent. In the case of South Africa, with the exception in 1980, it has been between negative two percent to 13 percent, maintaining a positive rate most of the years.

\section{Figure7: Interest Rate: Botswana and South Africa}

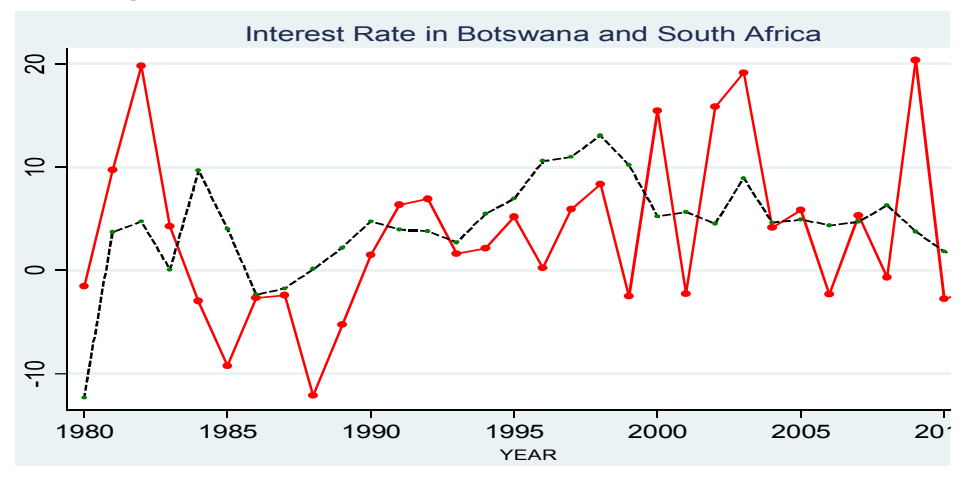

Source: Authors' calculation from the World Bank (2012) database 
30 | The Economic Journal of Nepal (Issue No. 149)

Figure 8 shows that the real interest rate in Lao PDR and Thailand indicating that Lao PDR has a steep decline of real interest rate during 1997 to 1999 due to Asian financial crisis (AFC), while Thailand had slightly up and down for the same period. Since 1999, Lao PDR's real interest has been above 10 percent throughout the period, while Thailand's real interest rate seems more stable in less than five percent level.

Figure 8: Interest Rate: Lao PDR and Thailand

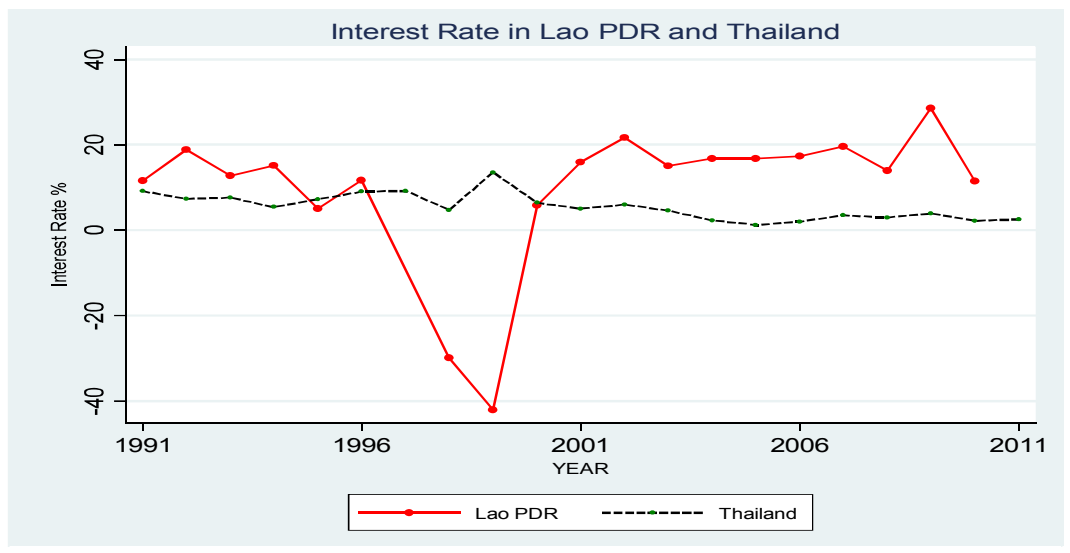

Source: Authors' calculation from the World Bank (2012) database.

Figure 9 shows the real interest rate series of Nepal and India for three and a half decades. Nepal's interest rates start at quite low in 1975 and then increased to almost 18 percent. Since then, it remains less than 10 percent throughout the period. India's real interest rate is always less than 10 percent after 1980. Since 1999, Nepal's interest rate series remains lower than that of India's.However, the pattern seems to be almost similar. Some cooperatives and private banks in the border area from India have still run the saving programs in the Terai region of Nepal. This situation makes interest rate of Nepal to follow India's interest rate structure.

Figure-9: Interest Rate: Nepal and India

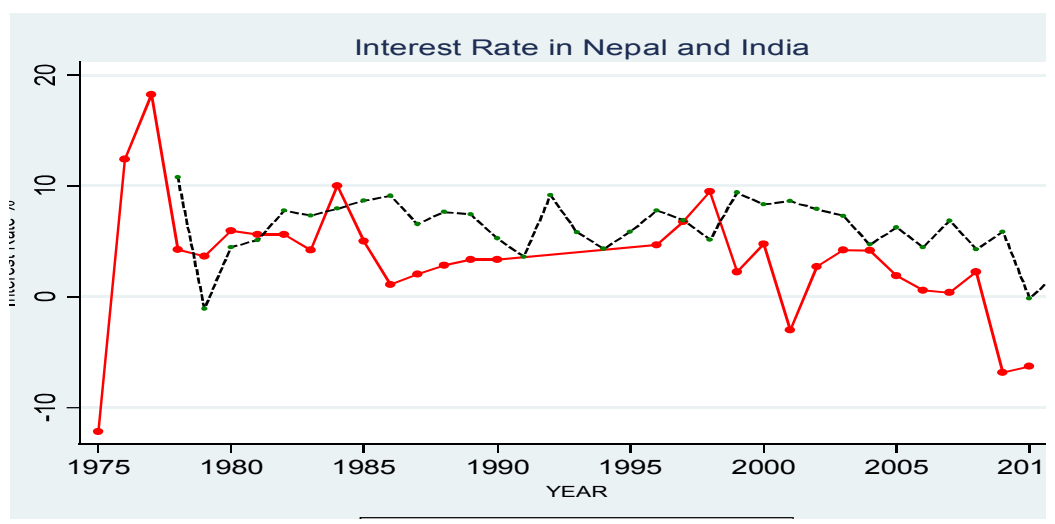

Source: Authors' calculation from the World Bank (2012) database 


\section{Exchange Rate}

Exchange rate in Botswana is determined based on the pegged value of her currency "Pula" to a basket of currencies that reflects the country's trading patterns, dominantly with South African "Rand". The performance of the Pula exchange rate as well as, broadly, the monetary policy framework has primarily reflected this objective. It maintained its membership to the Rand Monetary Area (RMA)- regional monetary Union composed of South Africa, Lesotho, Swaziland and Namibia.As Rand was pegged to US\$, South Africa had a decisive influence exchange rate (RMA). In 1976, Botswana formally withdrew from RMA and Pula was pegged to US\$ following Rand. Pula was pegged to US\$ until 1980. Figure10 reveals this scenario correctly that the change in the exchange rate in Botswana's Pula and South Africa's Rand have moved together for the entire period of 1960 to 2010. Both series look they are fully integrated.

\section{Figure10: Exchange Rate: Botswana and South Africa}

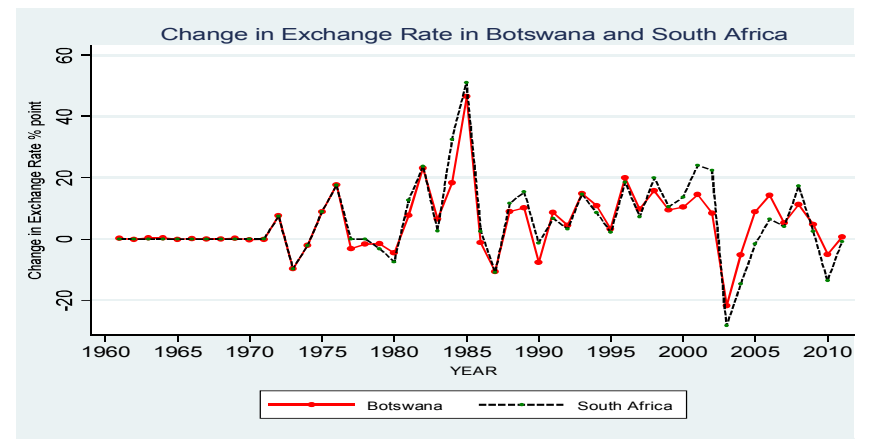

Source: Author's calculation from the World Bank (2012) database

The exchange rate of Lao PDR's currency "Kip" has a stabilised exchange rate regime visà-vis the 'Thai Baht' and the U.S.\$. Because of this situation, the change in the exchange rate is not strongly aligned with the "Baht". As seen in Figure11, the exchange rate of 'Kip' highly fluctuates with some exception until 2001, and then, it has closely followed to the "Baht".

Figure 11: Exchange Rate: Lao PDR and Thailand

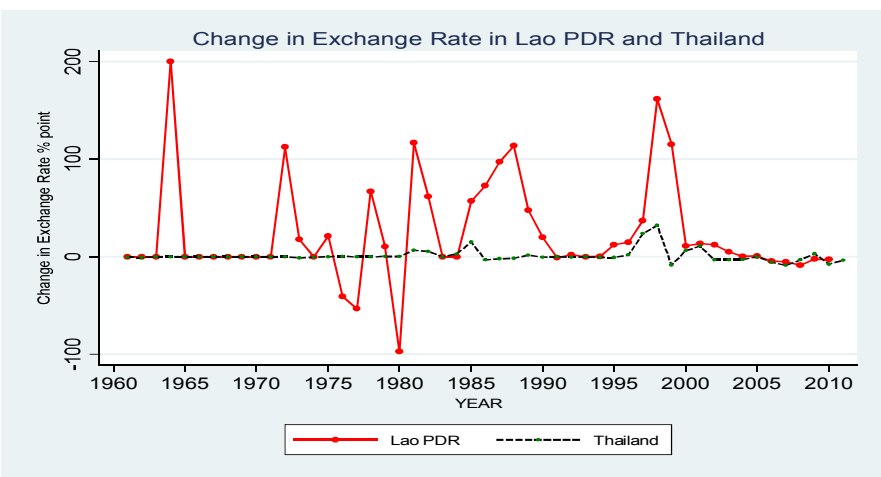

Source: Authors' calculation from the World Bank (2012) database 
In terms of the exchange rate, Nepalhas maintained apeg "Rupee" to the Indian "Rupee" and a float with US\$. Figure12 shows that the change in exchange rate patterns in these currencies has followed an almost similar structure, basically since the mid-1990s. Both currencies had fluctuated heavily in late-1960s and early 1990s substantially.

Figure12: Exchange Rate: Nepal and India

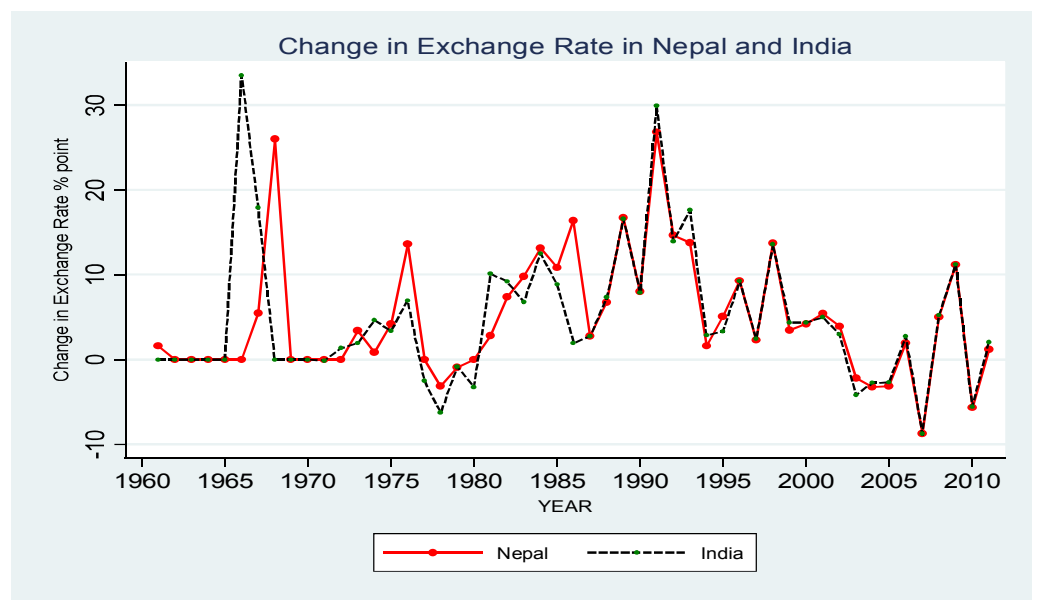

Source: Authors' calculation using the data from World Bank (2012) database

\section{Conclusions}

This paper analyses the different macroeconomic indicators of three landlocked developing countries with a particular interest in identifying whether these indicators are influenced by Gulliver effect. For this purpose, three landlocked developing countries were selected from three different regions, that is, Botswana from the Africa region, Lao PDR from the East Asian region and Nepal from South Asia. Analysing this diverse nature of landlocked countries would make sense to generalise the findings in other landlocked countries' case too. Before analysing the macroeconomic variables, the study analyses their trade with their big neighbour based on trade between the countries and size of economies. From this, it found the Gulliver effect in trade.

One crucial point is that these landlocked countries, by nature, depend on the infrastructure of their neighbour for international trade. For this purpose, naturally, they select their wealthier neighbour to minimise trade costs. On the other hand, some landlocked countries may not have any option left. It found the heavy dependenceon the neighbour of Nepal, Lao PDR and Botswana in the respective order for trade. This dependency has limited the trading capacity of the countries, thus has economic growth performance has been affected as replicated in their economic status.

Doubted that not only the trade but also the macroeconomic policies of the landlocked 
countries have Gulliver effect. This means that these landlocked countries' macroeconomic policies follow their Gulliver neighbour's macroeconomic policies largely. To know about this doubt, the paper analysed the significant macroeconomic variables of these landlocked countries' and their big neighbours'.

The findings from the analysis support our doubt to become real. The study found that significant macroeconomic variables of these landlocked developing countries move closelyfollowing a similar pattern, not always but in most of the time, with those of Gulliver neighbour but at different magnitude. In terms of the consumer price index, Botswana and South Africa have an almost similar pattern with of Nepal and India. Lao PDR and Thailand have a slightly different pattern. This might be due to the size of the economies of these countries. This means more gaps in the size of the economy causes more strong Gulliver effect.

In terms of interest rate, Botswana and South Africa followssimilar path, but Botswana's rate is more fluctuated. One notable point here is that both interest rates do not move together but move in the same direction with some exception. Lao PDR's and Thailand's interest rate do not precisely follow the same pattern but again seems Lao PDR's one is guided mainly by Thailand's in most of the period. Nepal's and India's pattern shows moving in the same direction in most of the period.

The study found that the exchange rate hasa stronger tie in all countries' cases due to exchange rate policies adopted by these countries. Therefore, it concludes that, primarily, there is Gulliver effect in the macroeconomic policies of landlocked developing countries. This relationship of the macroeconomic variables should be well noted while formulating macroeconomic policies of landlocked developing countries.

\section{References}

Acemoglu, D., Johnson, S.,\& Robinson, J. A. (2001). An African success story: Botswana, technical report, MIT, Department of Economics, Working Paper, No. 01-37.

Beaulier, S. A. (2003). Explaining botswana's success: the critical role of post-colonial policy. Cato J., 23, 227.

Blejer, M. I. \& Szapary, G. (1991). The 'Gulliver' effect and the 'Optimal Divergence' approach to trade policies: The case of Nepal, WorldDevelopment 19(2-3), 255-262.

Charaf $\square$ Eddine, N., \& Strauss, I. (2014). The ten commandments of applied regional integration analysis: the African case. African Development Review, 26(S1), 7-20.

Heston, A., Summers, R.,\& Aten, B. (2012). Penn world table version-7.1, Online (Accessed on 13/09/2012).

Hillbom, E. (2011). Botswana: A development-oriented gate-keeping state. African Affairs, $111(442), 67-89$. 
34 | The Economic Journal of Nepal (Issue No. 149)

Kyophilavong, P., Uddin, G. S., \& Shahbaz, M. (2016). The nexus between financial development and economic growth in Lao PDR. Global Business Review, 17(2), 303317.

Paudel, R.C. (2014). Trade Liberalisation and Economic Growth in Developing Countries: Does Stage of Development Matter? Crawford School Research Paper, 14-13.

Paudel, R. C. (2014a). Export performance in developing countries: A comparative perspective.Arndt-Corden Department of Economics, Crawford School of Economics, and Government, ANU College of Asia and the Pacific.

Paudel, R. C., \& Kankesu, J. (2009). Financial Liberalisation and Performance in Sri Lanka. South Asia Economic Journal, 10(1), 127-156.

Sharma, K., \& Bhattarai, B. (2013). Aid, policy, and growth: The case of Nepal. Journal of Economic Issues, 47(4), 895-910.

St John, R. B. (2006). The political economy of Laos: Poor state or poor policy? Asian Affairs, 37(2), 175-191.

Shrestha, M. B. (2005). Financial liberalisation in Nepal, Ph.D. thesis, School of Economics, University of Wollongong, Australia.

Thapa-Parajuli, R. B., \& Devkota, N. (2016). Impact of climate change on wheat production in Nepal. Asian Journal of Agricultural Extension, Economics \& Sociology, 1-14.

Upadhaya, S. (2008). Energy crisis and Nepal's Potentiality. The Initiation, 2(1), 130-135.

World Bank (2012). World Integrated Trade Solution, WITS, online. URL:http://wits. worldbank.org (Accessed on 07/06/2012. 